\title{
A CADEIA DE TRANSMISSÃO EM “O RECADO DO MORRO”, DE GUIMARÃES ROSA
}

\section{Clarissa Catarina Barletta Marchelli \\ PUC-RIO clarissa.catarina@gmail.com}

\begin{abstract}
RESUMO: Este artigo analisa o processo de composição de uma canção popular, descrito no conto "O recado do morro", de Guimarães Rosa. A narrativa relata uma experiência de inspiração poética originária de uma mensagem de natureza profética. Para que o alerta da profecia chegasse ao seu destinatário, fora preciso uma sequência de codificação e recodificação da mensagem de um morro. Consideramos essa cadeia como um fluxo afetivo e efetivo, tal como descrito nos relatos dos bardos homéricos.
\end{abstract}

Palavras-chave: Inspiração. Poesia. Profecia. Homero. Guimarães Rosa.

\begin{abstract}
This article analyzes the process of composition of a popular song, described in the story "O recado do morro" of Guimarães Rosa. The narrative recounts a poetic inspiration experience originating from a prophetic nature message. For the alert prophecy reached its recipient, it was needed a coding and recoding sequence of the message of a hill. We regard this chain as an affective and effective flow as described in the reports of the Homeric bards.
\end{abstract}

Keywords: Inspiration. Poetry. Prophecy. Homer. Guimarães Rosa.

Em recente publicação do jornal francês Le Monde Diplomatique, o vice-governador da Malásia, Joseph Pairin Kitingan, alegou que o abalo sísmico ocorrido no monte Kinabalu, matando onze pessoas, fora uma resposta ao ultraje de alguns turistas estrangeiros que urinaram e tiraram fotos nus na montanha, desrespeitando, assim, sua sacralidade. Segundo a tradição local, o monte Kinabalu, cuja etimologia designa "lugar de repouso dos mortos", é considerado sagrado porque nele estão abrigados os espíritos de seus ancestrais. O vice-governador disse ainda que a falta de decoro dos visitantes confirma tal sacralidade 
que, por sua vez, não pode ser desconsiderada. Em linhas gerais na matéria, lemos a forma como deve ser feita a visita na região: "Les touristes sont obligés d'avoir recours aux services d'un guide pour escalader le mont, qui les invite à le traiter avec respect, ne pas crier ou jurer le temps de leur présence dans le lieu sacré."32.

Para além do ceticismo do jornal ocidental, que se furta à análise antropológica da tradição do povo autóctone malaio, temos em um conto de Guimarães Rosa uma mensagem muito semelhante à resposta do monte Kinabalu às infrações cometidas pelo grupo estrangeiro; algo como o eco do constrangimento de tom religioso. Ainda sobre o abalo sísmico malasiano, o vice-governador interpretara o voo de andorinhas sobre sua casa durante o almoço: "algo de ruim aconteceria".

Da notícia do periódico ao discurso ficcional, o constrangimento despertado no leitor de "O recado do morro" (ROSA, 2005) é exatamente o mesmo com a potencialidade interpretativa de sinais da natureza que alguns conseguem operar. A narrativa rosiana descreve a trajetória de composição de uma canção popular - cujo sentido é o alerta a um perigo - desde uma mensagem de uma montanha até o insight do seu compositor. Estamos falando de um discurso ficcional que problematiza tanto o próprio fazer do poeta quanto uma forma particular de se relacionar com os elementos da natureza.

Segundo o narrador desse conto, o próprio processo de inspiração está intimamente atrelado à capacidade de verbalização de uma profecia, capacidade essa inata em personagens pouco afeitas ao convívio social, a saber, artistas, crianças, loucos e, sobretudo,

${ }^{32}$ LE MONDE DIPLOMATIQUE: "Para escalar o monte, os turistas são obrigados a recorrer aos serviços de um guia, que os convida a tratar com respeito, a não gritar ou cometer injúrias durante a presença no local sagrado.”. In: LeMonde.fr., tradução nossa, acesso em 12 de jun. de 2015.

Revista Texto Poético | ISSN: 1808-5385 | Vol. 20 (1o sem-2016) - p. 224 
eremitas. Ao que parece, o autor dá a entender com essa estória que o deslumbre de um tema composicional decorre da decodificação de sinais emitidos pela natureza, decodificação essa somente realizável por quem, de algum modo, dá vazão àquilo que escapa às sistemáticas e criteriosas faculdades mentais cognitivas. Vejamos.

O conto trata de uma expedição científica pelo sertão mineiro, feita por um pesquisador alemão, acompanhado de um padre e um fazendeiro. Eram "três patrões, entrajados e de limpo aspecto, gente de pessoa" (ROSA, 2005, p. 28). Por contraste, o guia dessa viagem é Pedro Orósio, um homem que bem conhece o território sem nunca têlo estudado. Além de Pê Boi, alcunha do enxadeiro, segue também Ivo, outro lavrador igualmente desprovido de qualquer conhecimento teórico. Diante de pessoas relativamente cultas, compara-se Pedro Orósio:

De certo, segredos ganhavam, as pessoas estudadas; não eram para o uso de um lavrador como ele, só com sua saúde para trabalhar e suar, e a proteção de Deus em tudo. Um enxadeiro, sol a sol debruçado para a terra do chão, de orvalho a sereno, e puxando toda força de seu corpo, como é que há de saber pensar continuado? E, mesmo para entender ao vivo as coisas de perto, ele só tinha poder quando na mão da precisão, ou esquentado - por ódio ou por amor. Mais não conseguia. (Ib., p. 35).

Ao longo da expedição, o guia Pê Boi reflete sobre a própria vida em forma de solilóquios, dispondo-se a entrar em conformidade com um desejo interior. Esses solilóquios, por sua vez, parecem ser a única formulação imagética, ou "eventos de pensamento" - para usar uma expressão de Paul Ricoeur (2006, p. 177) -, de que Pedro é capaz de realizar. Flagra da sua única atitude reflexiva, os solilóquios operam como que digressões ao seu lugar de origem, difusas no anseio pelo 
casamento. Mais, a frequência com que Pedro se visualiza casado chega a ser dissonante com seu estado civil de fato: solteiro.

[...] Pedro Orósio entrava repentino num imaginamento: uma vontade de, voltando em seus Gerais, pisado o de lá, ficar permanecente, para os anos dos dias. Arranjava uns alqueires de mato, roçava, plantava o bonito arroz, um feijãozinho. Se casava com uma moça boa, geralista pelo também, nunca mais vinha embora... Era uma vontade empurrada ligeiro, uma saudade a ser cumprida. (ROSA, op. cit., p. 47).

Assim é que, a certa altura inquirido pelo cientista se era casado ou não, e sem condições de responder-lhe, frei Sinfrão faz um juízo da situação afetiva de Pê Boi ao pesquisador alemão:

Que o Pedro era ainda teimoso solteiro, e o maior bandoleiro namorador: as moças todas mais gostavam dele do que de qualquer outro; por abuso disso, vivia tirando as namoradas, atravessava e tomava a que bem quisesse, só por divertimento de indecisão. Tal modo que muitos homens e rapazes lhe tinham ódio, queriam o fim dele, se não se atreviam a pegálo era por sensatez de medo, por ele ser turuna e primão de força, feito um touro ou uma montanha. Aquele mesmo Ivo, que evinha ali, e que de primeiro tão seu amigo fora, andava agora com ele estremecido, por conta de uma mocinha, Maria Melissa, do Cuba, da qual gostavam. (Ib., p. 32-3).

A provocativa hesitação de Pedro por uma ou outra mulher desperta rivalidade com os demais camaradas: motivo pelo qual Pedro quase cai numa emboscada, não fosse a canção do violeiro Pulgapé, alcunha do amigo Laudelim, a fazer-lhe a advertência. Mais precisamente, o narrador de "O recado do morro" faz coincidir a traição que Pedro sofre dos colegas com o ardil da canção do Reimenino. Eis a passagem na qual o violeiro sente o impulso da composição: 
Mas o Laudelim cismara tanto e tanto, enquanto estava ouvindo, seu rosto se ensombreceu, logo se alumiou ainda mais. Cá que não esperava, ele propunha assim desses esquisitos. Ave, matutava. E mesmo, quando o Pedro Orósio o pegou pelo braço e ia levando, ele entreparou, asseteado, pé no ar. - "Isso é importante!" - disse. E pendurou cara, por escutar mais. - “... O extraordinário de importante... Tremer as peles... Cristãos sem o que fazer... Quero ver meu ouro... Um danado de extraordinário!..." O que? A tontaria do Coletor? Patarata! Mas, que é que se havia, se o Laudelim era mesmo assim - que dava de com os olhos não ver, ouvido não escutar, e se despreparava todo, nuvejava. Nunca se sabia de seus porfins. Ainda, ainda. E a-duro vinha vindo, mas quebrou para a banda da casa do Siô Tico, de onde se avistava todo o arraial, lá em baixo, e a várzea. - "Vou mais no cemitério não. Já achei..." Que é que podia ter achado? Se sentou debaixo do itapicurú, temperava o violão, apalpou as cordas. Com ele desse jeito, arredado crente, boas horas de perdidas se podia ter. Melhor, mesmo melhor, era a gente ir aproveitar o oco do mundo noutra parte, conceder que ele ficasse ficando. - "Vai embora inda não" - ele pediu. $O$ violão toava bem afinado. E perguntou: - "Por que é que você não desdiz dessa festa? Vem junto, se cantar...” “- Ah, não. Mulheres quero." O Laudelim mal ouvia. Relou as cordas, ponteando, silamissol cantava. Arrastou um rasgado. Pê-Boi se despediu. - "O Rei menino... Passagens fortes! A toque de caixa... Passagens fortes... Passagens fortes...” - o Laudelim deu resposta. (Ib., p. 86-7).

Contudo, até que esse impulso de criação alcançasse a articulação das mínimas unidades de sentido primeiramente veiculadas no recado do Morro da Garça, fez-se necessária uma longa jornada de significação e ressignificação do aviso captado pelo ermitão Malaquias. Avistado pelo grupo dos cinco homens, o eremita está a caminho da casa do irmão, Zaquias, a quem deseja aconselhar a não se casar. Zacarias e Malaquias dão título a dois livros do Antigo Testamento bíblico, homônimos dos profetas judeus. De acordo com 
os exegetas, ambos apelam à necessidade de reconstrução do templo, simbologia de um arrependimento, para que Javé possa voltar a ajudar $^{33}$. A mensagem de Malaquias, entretanto, ganha destaque no nosso ensaio hermenêutico, pois o profeta chama a atenção dos sacerdotes que permitem o divórcio de mulheres fiéis, acusando na origem da separação uma escolha prematura na mocidade. $\mathrm{O}$ último dos profetas define também o propósito do casamento:

Existe outra coisa que vocês fazem: gemem e choram, cobrindo de lágrimas o altar de Deus porque ele já não aceita mais os sacrifícios que vocês oferecem. E cada um de vocês pergunta: "Por quê?" É porque Deus sabe que você tem sido infiel à sua esposa, a mulher com quem se casou quando era moço. Ela era sua companheira, mas você quebrou a promessa que fez na presença de Deus de que seria fiel a ela. Não é verdade que Deus criou um único ser, feito de carne e de espírito? E o que é que Deus quer dele? Que tenha filhos que sejam dedicados a Deus. (Bíblia Sagrada, 1990, Ml., 2: 13-15).

Se justapusermos as imagens do Malaquias bíblico à imagem do Malaquias rosiano, veremos que o encontro deste com os cinco homens em expedição coincide com a significação do nome em hebraico, "mensageiro de Deus". A encarnação do profeta bíblico na personagem rosiana nos permite ainda aprofundar a semelhança entre as imagens. A partir do apelo e da reserva inerentes à união amorosa latente no irmão, Zacarias, e no protagonista, Pedro Orósio, podemos averiguar tamanha semelhança na passagem:

${ }^{33}$ Cf. LARA, V. L., 2009, p. 120: "Os ideais de Zacarias e Ageu parecem frustrados e Malaquias assumiu a denúncia do sistema que foi organizado em torno do Templo. $\mathrm{O}$ sacrifício entra em colapso porque o dízimo não é pago e há um empobrecimento dos sacerdotes e levitas. Outro problema era o casamento com estrangeiras, que na ótica do livro de Malaquias ameaça a identidade do povo.".

Revista Texto Poético | ISSN: 1808-5385 | Vol. 20 (1o sem-2016) - p. 228 
Mesmo o motivo de sua viagem era ir de visita ao seu irmão Zaquias, morador tão lontão, também numa gruta pequena, pegada com a Lapa do Breu, rumo a rumo com a Vaca-emPé. Porque tinha tido sabença de que o Zaquia andava imaginando se casar. E então ele achava obrigação de aviso de deixar seus trabalhos, por uns dias, e vir reconselhar $o$ irmão, tivesse juizo, considerasse, as paciências, não estava mais em era de pensar em mulher. E desse modo, pondo e, efeito. (ROSA, op. cit., p. 42).

Não pretendemos com a análise da passagem bíblica afirmar aquilo que a vida do próprio Guimarães Rosa desmentiria: a contingência do divórcio. Defendemos, sim, que a fonte de elaboração da personagem rosiana corrobora a hipótese de a inspiração poética (o processo de composição da canção de Laudelim) ser precedida de uma experiência de fundo místico-religioso (a escuta do recado do Morro da Garça pelo profeta Malaquias). Defendemos igualmente a hipótese da profecia do recado do morro reverberar em Pedro Orósio enquanto advertência à sua escolha amorosa.

Temos relativa dificuldade em admitir a validade de uma experiência mística no plano real, talvez devido à precária necessidade de sistematizar cada um dos fenômenos naturais. A história da literatura universal, entretanto, já depõe contra tamanha intolerância, apresentando desde a sua origem relatos de alterações psíquicas que escapam ao controle consciente dos poetas. Estamos nos referindo aos épicos da antiguidade clássica, olhando com cuidado e interesse os relatos encontrados em Homero e Hesíodo, e entendendo-os como encarnação de um modo de ser particular que dificilmente se acomodaria aos padrões de comportamento do pensamento crítico moderno.

A título de exemplo da enigmática origem do discurso ficcional, temos notícia da invocação que os poetas clássicos faziam às Musas na abertura de 
suas obras monumentais. Tal é a disposição dos poetas da Ilíada ${ }^{34}$ e da Odisseia $^{35}$, como de Hesíodo, em Teogonia ${ }^{36}$ e $O$ trabalho e os dias ${ }^{37}$. No bojo do segundo poema homérico, há ainda outra correspondência valorosa para a nossa atestação entre a atuação de uma divindade e desempenho do aedo $^{38}$. Estando Ulisses de passagem pela Esquéria sem, no entanto, ter revelado sua verdadeira identidade ao rei Alcínoo, o guerreiro pede ao bardo dos feácios, Demódoco, que narre o episódio do cavalo de madeira, emboscada maquinada por ele mesmo que permitiu a vitória grega sobre os troianos:

Ora começa de novo, e o cavalo de pau nos invoca, que por Epeio foi feito com a ajuda de Palas Atena, esse que o divo Odisseu com astúcia pôs dentro de Troia, cheio de heróis destemidos, que os muros sagrados saquearam.

Caso consigas cantar isso tudo de acordo com os fatos, logo darei testemunho perante o universo dos homens que recebeste de um deus benfazejo a divina cantiga.

(HOM., 2002, VIII, 492-8).

Consenso entre os helenistas, a estadia de Ulisses na ilha dos feácios é crucial para o retorno do guerreiro, pois será o mais nobre povo que proverá o náufrago com a devida embarcação ${ }^{39}$. Nesse

${ }^{34}$ HOMERO, Ilíada, I, 1: "Canta-me a Cólera - ó deusa! [...]”.

${ }^{35}$ Id., Odisseia, I, 1: "Musa, reconta-me os feitos do herói [...]".

${ }^{36}$ HESÍODO, Teogonia, 1: "Pelas Musas heliconíades comecemos a cantar".

${ }^{37}$ Id., O trabalho e os dias, 1-2: "Musas Piérias que gloriais como vossos cantos, / vinde! [...]"

${ }^{38}$ HOM., Odisseia, VIII, 73: "A Musa logo o incitou a falar sobre os feitos dos homens [...]".

${ }^{39}$ HEUBECK, A., WEST, S. e HAINSWORTH, J. B. A commentary on Homer's Odyssey, v. I. Oxford:Claredon, 1991, p. 342. "The world of Scheria is thus a Homeric world from wich war, the curse as well as the glory of the heroic age, has been removed (vi 200). At the same time it is the sort of toilless world for wich Hesiod yearned [...]. The natural amenities of Scheria, peace, leisure, abundant crops, are dreams special to no time

Revista Texto Poético I ISSN: 1808-5385 | Vol. 20 (1o sem-2016) - p. 230 
sentido, o testemunho que Ulisses dá à inspiração divina do bardo está inserido em uma gama de comportamentos modelares, indicando nossa hipótese de uma estreita hermenêutica entre o discurso ficcional e o religioso. Uma provável confirmação dessa relação é investigada pelo helenista E. R. Dodds, em Os gregos e o irracional, a qual nos permite avançar na argumentação:

Uma das conexões remete, como sabemos, de volta à tradição épica. Foi uma musa que tomou de Demódoco sua visão corporal, dando-lhe em troca por amor, algo melhor - o dom da canção. É também pela graça das musas, como diz Hesíodo, que alguns homens são poetas; assim como é pela graça de Zeus que outros são reis. Podemos garantir que isso não traduz ainda uma linguagem oca, servindo apenas de cumprimento formal aos poetas, como será o caso posteriormente, mas que se trata de uma linguagem com conotações religiosas. Até certo ponto, o significado disso é bastante simples: como todas as realizações que não dependem totalmente da vontade humana, a criação poética contém um elemento que não é "escolhido", mas sim "concebido". Para o grego antigo, dizer que a piedade é "concedida" quer dizer que ela é "divinamente concedida". Não fica muito claro em que consiste esse elemento "concedido", mas se considerarmos as ocasiões em que o poeta da Ilíada apela às musas para obter ajuda, veremos que o elemento em questão concerne ao conteúdo e não à forma. O poeta sempre pergunta às musas o que ele deve dizer, nunca como deve dizê-lo, e as questões são sempre de fato. (DOODS, 2002, p. 86).

Ao que parece, Dodds não está sozinho na defesa de uma linguagem tipicamente religiosa presente na base do discurso ficcional. Na mesma direção seguem as leituras do diálogo Íon, de Platão, que associam a inspiração poética a uma experiência de ordem divina.

and place: they were shared by Hebrew prophets (Isaiah 2: 2-4, Micah 4: 1-5) and classical poets (A. Suppl. 625-709, Eu. 937-87) alike.

Revista Texto Poético I ISSN: 1808-5385 | Vol. 20 (1o sem-2016) - p. 231 
Nesse diálogo, Íon, um rapsodo perito em Homero, confessa não saber por que é capaz de discorrer bem sobre a poesia épica, mas ser igualmente inábil em relação aos demais gêneros; ao que Sócrates justifica: "uma potência divina que te movimenta" 40 .

Apesar das inúmeras controvérsias que tal fala suscita entre os especialistas em Platão, cabe-nos aqui apenas destacar a afirmativa socrática do final do diálogo: "Pois bem, de nossa parte o mais belo pertence a ti, Íon, ser divino e não um técnico panegirista de Homero." ${ }^{41}$. Mais, ao longo do diálogo, Sócrates sugere algumas vezes que Íon só pode ser capaz de dizer e interpretar os versos homéricos porque está conectado ao poeta como um metal que se conecta a uma pedra imantada; e jamais por técnica ou conhecimento lógico-dedutivo. Demonstra Sócrates a Íon:

Essa pedra não só atrai os anéis mesmo de ferro, como os infunde poder, de modo a novamente fazê-los ter o mesmo poder que a pedra, isto é, atrair outros anéis, de maneira que às vezes se forma uma cadeia extremamente longa de anéis de ferro dependente uns dos outros; e é daquela pedra que pende a potência para todos esses anéis. Assim, a Musa mesma faz os inspirados; e através desses inspirados, outros se entusiasmando, formam uma cadeia dependurada. Com efeito, todos os poetas épicos, os bons, não por técnica, mas sendo inspirados e possuídos, dizem todos esses belos poemas. (PLATÃO, Íon, 533e).

Sobre a doutrina da inspiração, do diálogo Íon, comenta o filósofo contemporâneo, Fernando Muniz, em As artes do entusiasmo: a inspiração da Grécia antiga à contemporaneidade:

${ }^{40}$ PLATÃO, Íon, 533d.

${ }^{41} \mathrm{Ib} ., 542 \mathrm{~b}$

Revista Texto Poético I ISSN: 1808-5385 | Vol. 20 (1o sem-2016) - p. 232 
Podemos retirar algumas conclusões da doutrina: A analogia entre composição poética e a pedra magnética nos força a entender a doutrina do entusiasmo defendida por Sócrates como a forma mais extrema de intervenção psíquica. O poeta ou o rapsodo são éntheoi ${ }^{42}$, ou seja, "têm um deus dentro", são elos da cadeia transmissora emanada pela potência divina, não podem, consequentemente, estar de posse de sua razão, não podem estar em si mesmos. A intervenção expulsa de casa a consciência do transmissor e a ocupa. Estar entusiasmado e estar possuído são, portanto, expressões sinônimas. Daí não terem eles, poetas e rapsodos, nenhuma participação ativa no processo de composição. (MUNIZ, 2011, p. 41).

Ainda sobre a teoria da imantação em Platão, esclarece Muniz:

No modelo quaternário - Musa/poeta/rapsodo/audiência -, a diferença entre os elementos não é mais de ordem qualitativa, mas, sim, quantitativa ou de grau. Da Musa - a fonte - à audiência, é o mesmo fluxo de sentido que os perpassa, ainda que a intensidade possa sofrer redução. Mas essa redução seria ainda de ordem quantitativa. Não há, portanto, uma hermenêutica da decifração ou da revelação de um sentido oculto, o sentido simplesmente passa de um a outro, numa fluência absoluta, no modo da afetividade e do contágio. (MUNIZ, op. cit., p. 42).

Curioso aqui é notar a simetria esboçada na comparação entre a teoria da imantação de Platão e a sequência de vezes com que a primeira mensagem do Morro da Garça é repetida ao longo do conto de Guimarães Rosa, até ser incorporada na canção de Laudelim. A ambos os processos podemos chamar de contágio. Contágio, fluência absoluta, ou autônoma, talvez seja esse mesmo o movimento pelo qual todos os sete intérpretes do recado do morro estejam conectados entre

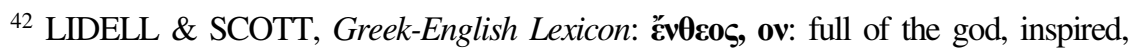
possessed: given by inspiration. 
si - imantados -, a ponto de a primeira escuta rudimentar do ermitão ser incorporada à canção de Laudelim para alertar o seu destinatário, Pê Boi, de uma eminente armadilha.

Nesse ponto, a recepção da composição do violeiro pela audiência, Pedro Orósio, sela uma significação unívoca entre o comércio da experiência do eremita Malaquias e a inspiração poética de Pulga Pé: advertir o enxadeiro da emboscada. Desse comércio decorre uma dissonância da nossa leitura do conto rosiano em relação à leitura que o filósofo contemporâneo faz do diálogo platônico. Embora tenhamos em vista o contexto de produção do diálogo, momento de surgimento e consolidação do raciocínio dedutivo, o discurso filosófico, em relativa competição com o discurso mítico, não podemos aderir à teoria platônica da imantação, segundo Muniz, desconsiderando o aspecto revelador que a poesia pode ter. Se, por um lado, a afetividade, potencialidade propagadora da mensagem entre os seus intérpretes, possibilita e garante que o recado inicialmente emitido por um elemento da natureza desprovido de linguagem articulada seja incorporado a uma canção popular, alcançando seu destinatário; por outro, estando Pedro Orósio constrangido com tamanha coincidência entre a cena descrita pelos versos da canção e o momento mesmo no qual se encontra rodeado pelos sete camaradas, o recado efetivou-se. Em outras palavras, cumpriu-se a profecia enunciada primeiramente pelo ermitão Malaquias.

Atestamos, assim, que haveria um sentido subjacente, oculto, no recado do morro mesmo a ser revelado na e através da escuta da canção - o alerta ao lavrador Pedro Orósio do ardil planejado pelos próprios camaradas. Tal conclusão nos obriga ainda a afirmar que, por mais imantados que estejam os elos da cadeia entre si por afecção, ou contágio, o movimento do conteúdo da mensagem desde o interior do 
planeta Terra em direção ao interior do poeta não poderia ser gratuito. Há, em $O$ recado do morro, não apenas uma afetiva cadeia, mas uma efetiva comunicação entre o Morro da Garça, os dois irmãos eremitas, o disparatado Guégue, o menino Joãozezim, o ex-seminarista Nomindome, o desatinado Coletor e o músico Pulga Pé, todos os sete intérpretes do recado do morro.

Como explicitado anteriormente, o diálogo Íon refuta a plausibilidade do conhecimento do poeta ser um conhecimento técnico, em função da inabilidade do rapsodo em recitar os poetas líricos com a mesma maestria com que recita os épicos. A essa predominância, Sócrates deduziu uma inspiração de ordem divina que, uma vez apossada do juízo do aedo, desencadearia uma força de propagação do conteúdo do poema desde a divindade inspiradora até o público que assiste à exibição. É precisamente com a canção popular do Rei menino que o enxadeiro Pedro Orósio consegue dar conta de si mesmo. $\mathrm{O}$ aspecto afetivo da mensagem, seu conteúdo indistinguível e inacessível aos próprios intérpretes é mesmo a mola propulsora da sua propagação. E o caráter efetivo da mensagem é a salvação mesma de Pedro Orósio da emboscada. Mesmo sem saber seu real significado, e porque o desconhecem, os sete intérpretes do recado do Morro da Garça o articulam e rearticulam, adaptando-o ao seu modo de se expressarem, cada qual a partir do seu modo próprio de enunciação. Dessa cadeia de propagação, o vislumbre da morte de Pedro Orósio.

Para nos assegurar da evidente influência que a composição de Laudelim exerce sobre Pê Boi, isto é, do real significado da canção do Rei menino a ser compreendido pelo lavrador, convoquemos o helenista Eric Havelock, para quem os poemas épicos homéricos agregam um valor inestimável da cultura clássica. Havelock destaca, em $A$ revolução da escrita na Grécia antiga, a relevância do conteúdo 
do poema, isto é, o emprego que a sociedade arcaica conferia ao assunto do poema homérico, chamando-o de "enciclopédia tribal":

Se o emprego original que se deu ao alfabeto grego teve de ser a transcrição previamente entesourada pelo código de uma cultura não-letrada, então os primeiros documentos do que chamamos "literatura" grega não podem ter sido composições livremente inventadas por artistas individuais. Seriam, antes, do tipo que em outro lugar denominei "enciclopédias tribais". É muito mais fácil aceitar essa característica no caso de Hesíodo do que no de Homero. Se a Ilíada e a Odisseia são transcriç̃̃es de informação oral elaborada e armazenada para reutilização cultural, por que insistem em disfarçar esse fato axial contando histórias sobre A cólera de Aquiles e o Retorno de Odisseu? (HAVELOCK, 1994, p.119, grifo nosso).

A análise de Havelock sobre o emprego factual das composições homéricas pelos gregos antigos dá margem à influência que o texto ficcional venha a exercer sobre um leitor/espectador, uma vez que tomamos a Ilíada e a Odisseia como obras inaugurais do discurso imagético ocidental. Nesse sentido, a obra rosiana em questão não só valida a perspectiva do helenista como atualiza a recepção do discurso ficcional outrora grego, a saber, o constrangimento da descoberta de um evento factual a partir da compreensão do desenrolar de uma cena dada no universo da ficção.

Prova cabal dessa íntima e inesgotável relação entre a afecção suscitada pela leitura de um texto literário e a experiência de vida concreta é o testemunho que a pesquisadora Walnice Nogueira Galvão dá, em Ler Guimarães Rosa hoje: um balanço, da inspiração que outra acadêmica teve ao ler as obras de João Guimarães Rosa e ao visitar os cenários nelas descritos: 
Outra vocação foi a de Marily Bezerra, diretora do filme de curtametragem Rio de Janeiro, Minas (1993), sobre a travessia do rio Urucuia no início de Grande Sertão: Veredas, que marcou o encontro inaugural entre Riobaldo e Diadorim. Geógrafa e membro de um grupo de geógrafos, sociólogos e antropólogos da USP que estudava nosso autor informalmente numa roda de leitura, Marily aprestou-se a conhecer a região. Ao deparar pessoalmente com o Morro da Garça, habitat e ente de "O recado do morro”, de Corpo de Baile, Marily não resistiu: comprou uma casinha de caboclo e mudou-se para lá. Tornou-se uma ativista da causa, fomentando a cultura própria da região, dando trabalho a bordadeiras, promovendo eventos, abrigando cantadores $e$ contadores de estórias, poetas e pintores. Juntamente com o prefeito, criou uma Casa de Cultura do Sertão, dedicada a Guimarães Rosa, destinada a promover patrimônio material e imaterial da região, oferecendo oficinas, apresentações $e$ excursões. Uma de suas contribuições é a criação da Caminhada Literária, realizada uma vez por ano, em que os integrantes percorrem trechos do cerrado do Morro da Garça, lendo e teatralizando fragmentos de "O recado do morro", acompanhados de guias especializados e de violeiros. (CITADOS por CHIAPPINI, L. e VEJMELK, M., 2009, p. 17-8).

Uma última análise, então, na nossa leitura do conto "O recado do morro" se faz necessária para que possamos averiguar com mais acuidade a hipótese da inspiração poética em Guimarães Rosa jazer numa experiência de ordem místico/religiosa: o próprio processo de transmissão do conteúdo da mensagem do morro. Tendo sido uma vez compreendida a captação dessa mensagem geodésica pelo poeta Laudelim, através de uma cadeia contagiosa de envio e reenvio que atualiza a teoria da imantação descrita no diálogo Íon, é forçoso admitir que a inspiração poética tanto em Platão quanto em Guimarães Rosa se dá via entusiasmo. Daí fazermos a sequência inversa daquela apresentada na estória do encadeamento da transmissão e retransmissão do recado do morro, começando pela recepção de Pedro Orósio, isto é, pelo constrangimento da compreensão do sentido último da canção do Rei menino: 
Aí então os Sete matavam o Rei, à traição. Traição... Caifaz... Parecia coisa que tinha estado escutando aquilo a vida toda! Palpitava o errado. Traição? Ah, estava entendendo. Num pingo dum instante. Olhou aqueles, em redor. Sete? Pois não eram sete?! Estarreceu, no lugar. Soprou. - "Doidou, Pê? Que foi?" Traição, de morte, o dano dos cachorros! (ROSA, op. cit., p. 103).

Na escuta dessa canção, Pê Boi parece ter se dado conta justamente da advertência da emboscada preparada pelos camaradas contra ele, trecho central da composição do amigo Pulgapé:

Quando o Rei era menino

já tinha espada na mão

e a bandeira do Divino

com o signo-de-salomão.

Mas Deus marcou seu destino:

de passar por traição.

Doze guerreiros somaram

pra servirem suas leis

- ganharam prendas de ouro

usaram nomes de reis.

Sete deles mais valiam:

dos doze eram um mais seis...

Mas, um dia, veio a Morte

vestida de Embaixador:

chegou da banda do norte

e com toque de tambor.

Disse ao Rei: - A tua sorte

pode mais que o teu valor?

Essa caveira que eu vi não possui nenhum poder! 
- Grande Rei, nenhum de nós

escutou tambor bater...

Mas é só baixar as ordens

que havemos de obedecer.

- Meus soldados, minha gente, esperem por mim aqui.

Vou à Lapa de Belém

pra saber que foi que ouvi.

E qual a sorte que é minha desde a hora em que eu nasci...

- Não convém, oh Grande Rei, juntar a noite com o dia...

- Não pedi vosso conselho, peço a vossa companhia!

Meus sete bons cavaleiros

flor da minha fidalguia...

Um falou pra os outros seis

e os sete com um pensamento:

- A sina do Rio é a morte, temos de tomar assento...

Beijaram suas sete espadas, produziram juramento.

A viagem foi de noite por ser tempo de luar.

Os sete nada diziam porque o Rei iam matar. Mas o Rei estava alegre e começou a cantar... [...]

(ROSA, op. cit., p. 94-96). 
Laudelim se entusiasma a compor a canção a partir do relato do Coletor, este, por sua vez, descrito como “[...] gira. Bem dizer, nem nunca tinha sido coletor, nem aquele era nome válido. Transtornos e desordens da vida, a peso disso ensandecera." (Ib., p. 83). Eis impressão de Coletor sobre o repentino sermão de um ex-seminarista na capela:

- “Uma Tana! Mistifo do homem... Por meu seguro... Onde é que já se viu?! O rei-menino... Bom, isso tem, na Festa: um rei menino, uma rainha menina, mais o Rei Congo e a Rainha Conga, que são os do próprio valor... O rei-menino, com a espada na mão! E o cinco-salomão: ara, só se vê disso, hoje em dia, é na bandeira do Divino, bordado rebordado... Baboseira! Morrer à traição, hora incerta, de tremer as peles... Doze é dúzia - isso é modo de falar? O que vale a gente é as leis... Quero ver, meu ouro. Não sou favoroso? Mais novecentos mil novecentos e noventa e nove mil milhões de milhões... A Morte - esconjuro, credo, vote vai, cã! Carece de prender esse Santos-Óleos, mandar guardar em hospícios... Vê lá se a Morte vem vindo, daí da banda do Norte, feito coisa de Embaixador, no represento de festa de cavalhada? E caixa $e$ tambor, quem estão batendo é essa gente do Sãtomé, à revelia... Cristãos sem o que fazer... Frioleiras... De que o Rei, pelos ermos, sete soldados, fidalgos e guerreiros da História Sagrada, e lapa de Belém, tudo por traição, dando conselho e companhia, ao pé da manjedoura, porque Deus baixou ordens... Novecentos milhões... Nove, seis e um - sete... Acabar? Posso dar meu juramento. Acaba nunca! Isso de mundo se acabar, de noite ou de dia, é invenção de gente pobre... Arrenego! Uma tana! Que seja p'ra o Capataz, e esta aqui p'ra o Malaquias!... (Ib., p. 85-86).

O ex-seminarista a quem Coletor se refere é também outra personagem enigmática e de parco convívio social. "Ninguém sabe onde ele assiste, não tem pouso nenhum", descreve o narrador a respeito do errático Nomindome. Dele, temos a versão mais entusiasmada do recado do morro, no altar: 
- ... Escutem minha voz, que é a do Anjo dito, o papudo: o que foi revelado. Foi o Rei, o Rei-Menino, com a espada na mão! Tremam, todos! Traço o sino de Salomão... Tremia as peles - este é o destino de todos: o fim de morte vem à traição, em hora incerta, é de noite... Ninguém queira ser favoroso! Chegou a Morte - aconforme um que é cá traz, um dessa banda do norte, eu ouvi - batendo tambor de guerra! Santo, santo, Deus dos Exércitos... A Morte: a caveira, de dia e de noite, festa na floresta, assombrando. A sorte do destino, Deus tinha marcado, ele com seus Doze! E o Rei, com os sete homens-guerreiros da História Sagrada, pelos caminhos, pelos ermos, morro a fora... Todos tremeram em si, viam o poder da caveira: era o fim do mundo. Ninguém tem tempo de salvar, de chegar até na Lapinha de Belém, pé da manjedoura... Aceitem meu conselho, venham em minha companhia... Deus baixou as ordens, temos só de obedecer. É o rico, é o pobre, o fidalgo, o vaqueiro e o soldado... Seja Caifaz, seja Malaquias! E o fim é à traição. Olhem os prazos... (Ib., p. 80).

A quarta e central transmissão do recado do morro é a interpretação de Guégue, "o bobo da fazenda” (Ib., p. 60), espécie de leva e traz da família de dona Vininha. O louco narra ao exseminarista, quando de um encontro fortuito no caminho desviado:

- A bom, no Bõamor: foi que o Rei - isso do Menino - com espada na mão, tremia as peles, não queria ser favoroso. Chegou a Morte, com a caveira, de noite, falou assombrando. Falou foi o Catraz, Qualhacôco: o da Lapinha... Fez sinosaimão... Mas com sete homens, caminhando pelos altos, disse que a sorte quem marca é Deus, seus Doze Apóstolos, e a Morte batendo jongo de caixa, de noite, na festa, feito História Sagrada... Querendo matar à traição... Catraz, o irmão dum Malaquia... Ocê falou: a caveira possui algum poder? É o fim do mundo? (Ib., p. 69). 
Guégue tentara passar a Nomindome o que captara da transmissão do menino Joãozezim que, sem domínio pleno da linguagem falada, encena com gestos aquilo que entendera da mensagem de Zaquias:

- "Um morro, que mandou recado! Ele disse, o Catraz, o Qualhacôco... Esse Catraz, o Qualhacôco, que mora na lapinha, foi no Salomão, ele disse... E tinha sete homens lá, com o irmão dele, caminhando juntos, pelos altos... Você acredita?"

E o menino Joãozezim primeiro quis olhar de cima para baixo o Guégue; não podendo, por ser pequeno, então se acocorou, e ficou agachado assim, o pescoço esticado para o ar: parecia um pato branco. O Guégue ouvia. Só lhe faltava crescer as orelhas e avançá-las, muito peludas. Babeava, mostrava os dois cacos de dentes. E se ria.

- O recado foi este, você escute certo: que era o rei... Você sabe o que é rei? $O$ que tem espada na mão, um facão comprido e fino, chama espada. Repete. A bom... o rei tremia as peles, não queria ser favoroso... Disse que a sorte quem marca é Deus, seus Apóstolos. E a Morte, tocando caixa, naquela festa. A Morte com caveira, de noite, na festa. E matou à traição... (Ib., p. 62).

A gesticulação do menino é todo o poder mimético de que dispõe para conseguir impressionar o bobo Guégue, tal como ele mesmo se impressionara na condição de criança, ao ouvir conversas de gente grande. "[...] um caxinguelê de ladino: piscava os olhinhos, arregalava os olhos, de bonitas crescidas pestanas, e divisava a gente de cima a fundo, nada não perdia." (Ib., p. 55), Joãozezim entre os adultos fora quem registrara o recado, prestando atenção ao relato de Zaquias sobre a visita de seu irmão, Malaquias. Dentre outras coisas ${ }^{43}$, uma das

${ }^{43}$ ROSA, op. cit., p. 58: "Mas o Malaquia conversava com ele coisas de religião, também".

Revista Texto Poético | ISSN: 1808-5385 | Vol. 20 (1o sem-2016) - p. 242 
conversas que Zaquias teve com o irmão fora sobre o recado que ouvira:

- "E um morro, que tinha, gritou, entonces, com ele, agora não sabe se foi mesmo p'ra ele ouvir, se foi pra alguns dos outros. É que tinha uns seis ou sete homens, por tudo, caminhando mesmo juntos, por ali, naqueles altos... E o morro gritou foi que nem satanaz. Recado dele. Meu irmão Malaquia falou del-rei, de tremer peles, não querendo ser favoroso... Que sorte de destino quem marca é Deus, seus Apóstolos, a toque de caixa da morte, coisa de festa... Era a Morte. Com a caveira, de noite, feito História Sagrada... Morte à traição, pelo semelhante. Malaquia dixe. A Virgem! Que é que essa estória de recado pode ser?! Malaquia meu irmão se esconjurou, recado que ninguém se sabe se pediu...” (Ib., p. 59).

Por fim, a escuta originária de toda a corrente de transmissão do recado do morro se dá com Gorgulho: "Um velhote grimo, esquisito, que morava sozinho dentro de uma lapa, entre barrancos e grotas uma urubuquaquara - casa dos urubus, uns lugares com pedreiras. $\mathrm{O}$ nome dele, de verdade, era Malaquias." (Ib., p. 37):

- Que que disse? Del-rei, ô, demo! Má-hora, esse Morro, áspero, só se é de satanaz, ho! Pois-olhe-que, vir gritar recado assim, que ninguém não pediu: é de tremer as peles... Por mim, não encomendei aviso, nem quero ser favoroso... Del-rei, del-rei, que eu cá é que não arrecebo dessas conversas, pelo similhante! Destino, quem marca é Deus, seus Apóstolos! E que toque de caixa? É festa? Só se for morte de alguém... Morte à traição, foi que ele Morro disse. Com a caveira, de noite, feito História Sagrada, del-rei, del-rei!... (Ib., p. 47-48).

Curioso aqui é notar que, quando da escuta de Malaquias, o único a perceber que algo de extraordinário se dera entre o Morro da Garça e o eremita fora seu Alquiste, o cientista. Espantado, o cientista desejava saber: 
- O! Ack! - glogueou seo Olquiste, igual um pato. Queria que o Gorgulho junto viesse. - Troglodyt? Troglodyt? inquiria, e, abrindo grande a boca, rechupava um ohh!... Quase se despencando, desapeou. Frei Sinfrão e seo Jujuca desmontaram também. (Ib., p. 40).

Concluímos que, se seu Olquiste demonstra curiosidade pelas relações afetivas de Pê Boi no início da jornada, o que o pesquisador intentara descobrir ao longo da expedição não fora senão a efetiva comunicação entre os elementos da Natureza e os homens, viabilizada tão somente pelos pontífices em questão: eremitas, crianças, loucos e artistas. Por outro lado, se o recado do morro tem como motivo o alerta de uma emboscada, o que nós intentamos com esse trabalho não fora senão alcançar o conteúdo desse diálogo, a saber, a advertência relativa ao apelo e à reserva inerentes ao matrimônio - evento de pensamento, sonho de Pedro Orósio. Em outras palavras, a indecisão do protagonista por esta ou aquela consorte desperta o ciúme dos colegas, que planejam uma armadilha. Para tamanha complexidade, somente uma intervenção sutil e de outra ordem - uma canção inspirada.

\section{Referências}

ARAUjO, H. V. de. A raiz da alma. São Paulo: Edusp, 1992.

Bíblia Sagrada. Trad. Ivo Storniolo e Euclides Martins Balancin. São Paulo: Paulus, 1990.

DeleuzE, G. e GUATTARI, F. Mil Platôs: capitalismo e esquizofrenia, v. 4. Trad. Suely Rolnik. Rio de Janeiro: Ed. 34, 1997.

DODDS, E. R. Os gregos e o irracional. Trad. Paulo Domenech Oneto. São Paulo: Escuta, 2002. 
CHIAPPINI, L. e VEJMELKA, M. (Org.). Espaços e caminhos de Guimarães Rosa: dimensões regionais e universalidade. Rio de Janeiro Nova Fronteira, 2009.

HAVELOCK, E. A. A revolução da escrita na Grécia e suas consequências culturais; trad. Ordep José Serra. São Paulo: Editora da UNESP, 1996.

HESÍODO. Os trabalhos e os dias. Trad. Mary de Camargo Neves Lafer. São Paulo: Iluminuras, 2006.

. Teogonia, a origem dos deuses. Trad. Jaa Torrano. São Paulo: Iluminuras, 2001;

HEUBECK, A.; WEST, S. e HAINSWORTH, J. B. A commentary on Homer's Odyssey, v. I. Oxford: Clarendon, 1991.

HOMERO. Ilíada. Trad. Carlos Alberto Nunes. Rio de Janeiro: Ediouro, 2001.

Odisseia. Trad. Carlos Alberto Nunes. 5. ed. Rio de Janeiro: Ediouro, 2002.

LARA, Valter Luis. A Bíblia e o desafio da interpretação sociológica. São Paulo: Paulus, 2009.

Le Monde Diplomatique. Disponível em:

$<$ http://bigbrowser.blog.lemonde.fr/2015/06/11/nus-ils-seprennent-en-photos-devant-une-montagne-sacree-et-sont-accusesdavoir-cause-un-

seisme/?utm campaign=Echobox\&utm medium=Social\&utm_sour ce=Facebook $>$. Acesso em: 12 jun. 2015.

LIDDELL \& SCOTT'S. Grek-English Lexicon. Oxford: Clarendon, 1949. 
MUNIZ FERNANDO (Org.). As artes do entusiasmo: a inspiração da Grécia antiga à contemporaneidade. Rio de Janeiro: 7 Letras, 2011.

PLATÃO. Íon. Trad. Humberto Zanardo Petrelli. Disponível em: http://www.consciencia.org/platao ion.shtml. Acesso em: 16 jun. 2015.

RICOEUR, P. Percurso do reconhecimento. Trad. Nicolás Nyimi Campanário. São Paulo: Loyola, 2006.

ROSA, J. G. No Urubuquaquá, no Pinhém (Corpo de Baile). 9. ed. Rio de Janeiro: Nova Fronteira, 2001. 